\title{
Epidemiological status of bovine leptospirosis in the State of Paraná, Brazil
}

\section{Situação epidemiológica da leptospirose bovina no estado do Paraná}

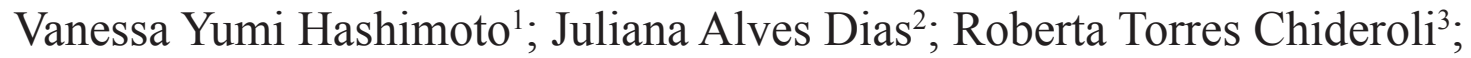 \\ Jean Carlos Alves Barbara ${ }^{3}$; Talita Bianca Brunharo ${ }^{3}$; Leonardo Hermes Dutra \\ Maria do Carmo Pessôa Silva ${ }^{5}$; Ernst Eckehardt Muller ${ }^{6}$ Julio Cesar de Freitas ${ }^{6^{*}}$
}

\begin{abstract}
The objective of this study was to determine the prevalence of antibodies against Leptospira spp and their geographic distribution and to identify the risk factors associated with this disease in cattle herds with reproductive activity in the state of Paraná. A total of 14163 females aged $\geq 24$ months originating from 1926 herds that were not vaccinated against Leptospira spp were evaluated. To detect the Leptospira spp antibodies, all serum samples were submitted for a microscopic serum-agglutination test (MAT). An epidemiological questionnaire was performed at each farm visited to characterize the management practices and study the risk factors associated with the presence or absence of Leptospira spp. To perform geoprocessing, the geographical coordinates of each farm were recorded with a Global Positioning System (GPS), which were then used to create a map. The apparent prevalence of bovine leptospirosis in the herds was the parameter used to generate the final risk map. The apparent prevalences of seropositivity in the herds and animals in Paraná state were 54.28\%(95\%CI:52.05$56.51)$ and $37.70 \%(95 \% \mathrm{CI}: 34.54-40.86)$, respectively. Multiple logistic regression analysis revealed that the risk factors associated with leptospirosis due to any serovar were the rental of grazing areas $[\mathrm{OR}=1.91(1.36-2.68)]$, presence of horses $[\mathrm{OR}=1.59(1.28-1.97)]$, presence of $>20$ females $\geq 24$ months of age $[\mathrm{OR}=2.25(1.46-3.49)]$, presence of $>49$ bovines [OR=2.78(1.82-4.26)], purchase of animals for reproduction $[\mathrm{OR}=1.96(1.59-2.41)]$ and presence of calving pens [OR=1.32(1.04-1.68)]. Risk factors for leptospirosis due specifically to serovar Hardjo were the presence of $>49$ bovines $[\mathrm{OR}=3.05(1.94-4.80)]$, presence of $>20$ females $\geq 24$ months [OR=2.38(1.50-3.79)], presence of horses $[\mathrm{OR}=1.87(1.45-2.43)]$, purchase of animals for reproduction $[\mathrm{OR}=2.14(1.68-2.72)]$ and rental of grazing areas $[\mathrm{OR}=2.22(1.54-3.21)]$. Geographically, seropositivity to Leptospira spp by MAT identified the regions North/Northwest and Southwest in the state as the areas with a higher risk of disease occurrence.
\end{abstract}

Key words: Epidemiology, leptospirosis, microscopic agglutination test, prevalence, risk factors, spatial distribution

\footnotetext{
${ }^{1}$ Discente de Doutorado, Programa de pós graduação em Ciência Animal, Dept ${ }^{\circ}$ de Medicina Preventiva, Universidade Estadual de Londrina, UEL, Londrina, PR, Brasil. E-mail: hashimotovanessa@gmail.com

2 Pesquisadora, Empresa Brasileira de Pesquisa Agropecuária, EMBRAPA, Porto Velho, Rondônia, Brasil. E-mail: juliana.dias@ embrapa.br

3 Discentes do Curso de Graduação em Medicina Veterinária, UEL, Londrina, PR, Brasil. E-mail: roberta_tc@hotmail.com; jeanalves2005@yahoo.com.br; tata_peixes@hotmail.com

${ }^{4}$ Consultor do Ministério da Saúde, MS, Brasília, Distrito Federal, Brasil. E-mail: leonardodutrars@hotmail.com

5 Agência de Defesa Agropecuária do Paraná, ADAPAR, Curitiba, Paraná, Brasil. E-mail: pessoa@adapar.pr.gov.br

${ }^{6}$ Profs. Drs., Dept ${ }^{\mathrm{o}}$ de Medicina Veterinária Preventiva, DMVP, UEL, Londrina, Paraná, Brasil. E-mail: muller@uel.br; freitasj@ uel.br

* Author for correspondence
} 


\section{Resumo}

O objetivo deste trabalho foi determinar a prevalência de anticorpos anti-Leptospira spp, sua distribuição espacial e identificar os fatores de risco associados à doença nos rebanhos bovinos com atividade reprodutiva do estado do Paraná. Foram estudadas 14.163 fêmeas com idade $\geq 24$ meses, provenientes de 1.926 rebanhos não vacinados contra a leptospirose. Para detectar anticorpos contra a Leptospira spp, todos os soros foram submetidos a prova de soroaglutinação microscópica (SAM). . Em cada propriedade visitada foi aplicado um questionário epidemiológico, que permitiu a caracterização das práticas de manejo empregadas e o estudo dos fatores de risco associados com a presença ou ausência da Leptospira spp. Para o geoprocessamento, as coordenadas geográficas de cada propriedade foram obtidas por meio de aparelhos de posicionamento global por satélite (GPS), as quais foram utilizadas para a confecção do mapa. A prevalência aparente de propriedades e animais sororeagentes no estado foi de 54,28\%(95\%CI:52.05-56.51) e 37,70\%(95\%CI:34.5440.86), respectivamente. $\mathrm{Na}$ análise de regressão logística multivariada, foram identificados como fatores de risco para a infecção para qualquer sorovar de Leptospira spp: aluguel de pasto $[\mathrm{OR}=1.91(1.36-2.68)]$; presença de equinos $[\mathrm{OR}=1.59(1.28-1.97)]$; presença de $>20$ fêmeas com idade $\geq 24$ meses $[\mathrm{OR}=2.25(1.46-3.49)]$; presença de $>49$ bovinos $[\mathrm{OR}=2.78(1.82-4.26)]$; compra de reprodutores [OR=1.96(1.59-2.41)] e presença de piquete de parição [OR=1.32(1.04-1.68)]. Os fatores de risco para a infecção pelo sorovar Hardjo foram presença de $>49$ bovinos [OR=3.05(1.94$4.80)]$, presença de $>20$ fêmeas com idade $\geq 24$ meses [OR=2.38(1.50-3.79)]; presença de equinos $[\mathrm{OR}=1.87(1.45-2.43)]$; compra de reprodutores $[\mathrm{OR}=2.14(1.68-2.72)]$ e aluguel de pasto $(\mathrm{O} . \mathrm{R}=2,22$; I.C $=1,54-3,21)$. $[\mathrm{OR}=2 \cdot 22(1.54-3 \cdot 21)]$. A visualização espacial dos rebanhos sororeagentes na SAM permitiu identificar as regiões norte/noroeste e sudoeste como as áreas de maior ocorrência e risco da enfermidade no estado.

Palavras-chave: Distribuição espacial, epidemiologia, fatores de risco, leptospirose, prevalência, soroaglutinação microscópica

\section{Introduction}

Among the diseases that involve reproduction, leptospirosis is considered one of the most important diseases in Brazil, affecting the production and productivity of herds (BRASIL, 1995). The economic losses caused by bovine leptospirosis are directly or indirectly related to reproductive failure, abortion and the cost of veterinary care, medications, laboratory tests and vaccines. Reproductive problems are the most significant clinical manifestations of leptospirosis in cattle and are often the only symptom observed in the herd (FAINE et al., 1999).

In cattle herds, the dissemination and maintenance of leptospirosis are characterized mainly by the presence of infected animals or asymptomatic carriers that eliminate the bacteria in the urine, cervical-vaginal discharge, aborted fetuses or placenta (FAINE et al., 1999). Other factors such as the presence of serovars of leptospires in the region, the concurrent infection of several different species of animals, the presence of wild animals, the environmental and climatic conditions and herd management may also influence the risk of exposure of cattle to the microorganism (ELLIS, 1984).

Serologic surveys carried out in Brazil reveal the presence and high frequency of leptospirosis in cattle herds (FAVERO et al., 2002; GENOVEZ et al., 2004; CASTRO et al., 2008; FIGUEIREDO et al., 2009; HASHIMOTO et al., 2010, 2012). In the state of Paraná, previous studies on bovine leptospirosis were restricted to certain regions, making it impossible to evaluate the true impact and frequency of this disease within the state. Therefore, further studies are necessary to 
elucidate the epidemiological status of the disease in Paraná.

Considering the lack of epidemiological information on bovine leptospirosis in the state of Paraná, the goal of this study was to determine the prevalence of antibodies against Leptospira spp and their spatial distribution in the state and to identify the risk factors associated with this disease in cattle herds with reproductive activity.

\section{Materials and Methods}

\section{Study population}

The study was conducted in the state of Paraná in Southern Brazil. The statistic delineation, serum samples and information regarding the selected farms were the same as those employed in the study of bovine brucellosis in the state of Paraná in the context of the National Program for Control and Eradication of Brucellosis and Tuberculosis (PNCEBT), proposed by the Animal Defense Department, Ministry of Agriculture, Livestock and Food Supply and by the Epidemiology Division of Secretary of Agriculture of Paraná (SEAB-PR).

For this study, the state was divided into seven different bovine production regions. The different production systems, management practices, types of breeding, average size of the herds and commercialization systems were evaluated for each region. Each region was integrated into a different regional administration office by the SEAB-PR (Figure 1). The census data used as the basis for the evaluation of samples and the apparent prevalence of Leptospira spp were the most recently updated data that were available (PARANÁ, 2001). Table 1 presents a summary of the census and also shows the sample population studied in each of the bovine production regions.

Figure 1. Map of the state of Paraná, showing the division of regions used in this study. The inset shows the location of the state of Paraná within Brazil.

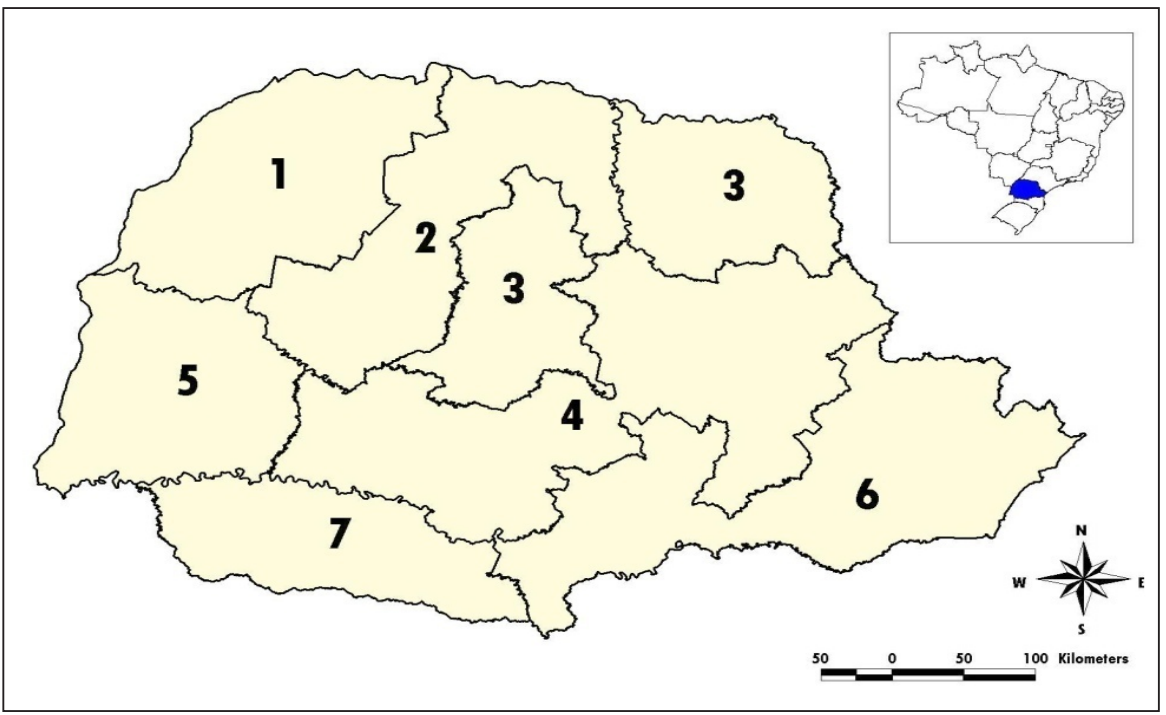


Table 1. Census data for the bovine population in the state of Paraná, Brazil, in 2001, according to bovine production regions (PARANÁ, 2001).

\begin{tabular}{|c|c|c|c|c|c|c|}
\hline \multicolumn{3}{|c|}{ Productive circuits } & \multirow{2}{*}{$\begin{array}{l}\text { Total herds with } \\
\text { reproductive } \\
\text { activities }\end{array}$} & \multirow{2}{*}{$\begin{array}{c}\text { Total females } \\
\text { aged } \geq 24 \\
\text { months }\end{array}$} & \multirow{2}{*}{$\begin{array}{l}\text { Sampled } \\
\text { herds }\end{array}$} & \multirow{2}{*}{$\begin{array}{l}\text { Sampled } \\
\text { females }\end{array}$} \\
\hline $\mathbf{N}^{\circ}$ & Region & $\begin{array}{c}\text { Regional Administration } \\
\text { Office }\end{array}$ & & & & \\
\hline 1 & North-west & Umuarama and Paranavaí & 23104 & 1140410 & 283 & 2730 \\
\hline 2 & $\begin{array}{l}\text { Mid-western/ } \\
\text { North }\end{array}$ & $\begin{array}{c}\text { Campo Mourão, Maringá and } \\
\text { Londrina }\end{array}$ & 20835 & 750002 & 280 & 2512 \\
\hline 3 & Far North & $\begin{array}{c}\text { Cornélio Procópio, Ivaiporã } \\
\text { and Jacarezinho }\end{array}$ & 27403 & 972554 & 274 & 2195 \\
\hline 4 & Mid-South & $\begin{array}{l}\text { Laranjeiras do Sul, } \\
\text { Guarapuava and Ponta Grossa }\end{array}$ & 42738 & 878916 & 274 & 1880 \\
\hline 5 & West & Cascavel and Toledo & 33451 & 616012 & 279 & 1898 \\
\hline 6 & South-east & $\begin{array}{l}\text { Curitiba, União da Vitória, } \\
\text { Paranaguá and Irati }\end{array}$ & 18616 & 173396 & 279 & 1271 \\
\hline 7 & South-west & $\begin{array}{l}\text { Francisco Beltrão and Pato } \\
\text { Branco }\end{array}$ & 44126 & 517315 & 257 & 1677 \\
\hline \multicolumn{3}{|c|}{ State of Paraná } & 210273 & 5048605 & $1926^{a}$ & $14163^{a}$ \\
\hline
\end{tabular}

Only herds that were not vaccinated against Bovine Leptospira spp were included in this study.

\section{Study design}

To estimate the apparent prevalence of positive herds and animals, a sampling study was developed in two stages. First, a random selection of herds from a pre-established number of farms was collected, which represents the primary sampling units. Within these primary units, a predetermined number of cows aged $\geq 24$ months were randomly selected (secondary units) to determine the Leptospira spp infection status of the herd.

The number of herds selected per region was estimated by the confidence level of the result, the desired level of accuracy and estimated value for prevalence (NOORDHUIZEN et al., 1997), using the formula for a simple random sample proposed by Thrusfield (1995) and Noordhuizen et al. (1997):

$$
\begin{aligned}
& n=\frac{Z_{\alpha}^{2} \cdot \sqrt{P(1-P)}}{d^{2}} \\
& n=\text { number of farms sampled per region; } \\
& Z_{\alpha}=\text { value of normal distribution for the } \\
& \text { confidence level of } 95 \% \text {; } \\
& P=\text { estimated apparent prevalence of } 50 \% ;
\end{aligned}
$$

$$
d=\text { accuracy of } 5 \%
$$

The random selection of herds was conducted using the registration of existing farms in SEAB$\mathrm{PR}$, taking into consideration the number of farms in the municipality and the number of farms sampled in the production regions. For each municipality, the existing farms were numbered, and the data was stored in Microsoft Excel 2000 ®.

The purpose of the sampling plan for the secondary units was to estimate the minimum number of animals requiring examination at each farm to enable classification of the farm as a focus or non-focus of Leptospira spp infection.

Herdacc version 3 software (University of Guelph) was used to determine the number of selected animals required from each herd to obtain sensitivity and specificity more than $90 \%$, taking into account the size of the population, an intra-herd apparent prevalence of $50 \%$ and the sensitivity and specificity of the diagnostic test used.

In herds of 99 or fewer females, a total of 10 females were sampled. Fifteen females were sampled from herds containing more than 99 
females. The selection of individual animals within the herd was conducted using a systematic random sampling procedure. A total of 14163 females aged $\geq 24$ months originating from 1926 herds that were not vaccinated against Leptospira spp were evaluated.

\section{Collection of blood samples and epidemiological data}

The fieldwork was conducted by veterinarians and technicians of SEAB-PR in the period between December 2001 and July 2002. On each farm visited, an epidemiological questionnaire was completed to characterize the management practices employed and to allow the study of risk factors associated with the presence or absence of Leptospira spp. During the visits, the geographic coordinates of each farm were recorded using a Global Positioning System (GPS), Garmin model $12 \mathrm{XL}^{3}$. Blood was collected into a vacuum tube, labeled for identification, by jugular venipuncture using a sterile disposable needle. Serum samples were stored in plastic microtubes and frozen at $-20^{\circ} \mathrm{C}$.

\section{Serological test for Leptospira spp}

For the detection of Leptospira spp antibodies, all serum samples were submitted for a microscopic serum-agglutination test (MAT), performed according to Faine et al. (1999), with a collection of living antigens that included the following serovars: Australis, Bratislava, Autumnalis, Butembo, Castellonis, Bataviae, Canicola, Whitcomb, Cynopteri, Fortbragg, Grippotyphosa, Hebdomadis, Copenhageni, Icterohaemorrhagiae, Panama, Pomona, Pyrogenes, Hardjo, Wolffi, Shermani, Sentot and Tarassovi. The antigens were stored at $28^{\circ} \mathrm{C}$ for 5 to 10 days in EMJH medium (Becton-Dickinson Biosciences/DIFCO/Detroit/ USA). Serum samples presenting $50 \%$ or more agglutinated Leptospira spp in the 1:100 dilution were considered positive; serial dilution was performed with these samples until the maximum positive dilution was determined.

In individual animals, the most common infecting serovar was that with the highest titer. With the exception of the association between serovars Hardjo and Wolffi, the animals that presented equal reactions to two or more serovars were excluded from this analysis and considered seropositive for Leptospira spp.

The most common infecting serovar in herds was the one that presented the highest titer and the highest number of positive reactions. The presence of at least one positive animal in a herd established the herd as a focus of leptospirosis in this study.

\section{Calculation of the apparent prevalence}

The sampling design allowed determination of the apparent prevalence of positive herds and of Leptospira spp seropositive adult females $(\geq 24$ months) in each region of Paraná and for the entire state. The estimated apparent prevalence values and the corresponding confidence intervals were calculated using EpiInfo 6.04d (DEAN et al., 1994).

Because the primary unit sample for each region was selected based on random systematic sampling (COCHRAN, 1977), the apparent prevalence of Leptospira spp foci was calculated using the number of positive herds and the number of herds sampled (DEAN et al., 1994).

For the total area of the state, because of the division of regions, the primary unit sample was considered to be a stratified random systematic sampling (COCHRAN, 1977). The parameters used for the calculation of the apparent foci prevalence were the status of the herd (Leptospira spp positive or negative), the region to which each herd belonged and the assigned weight of each herd sampled in the region. The assigned weight was calculated based on the ratio of the number of herds with reproductive activity to the total number of herds sampled in each region (DEAN et al., 1994). 
The apparent prevalence of seropositive adult females was calculated for each region and also for the whole state. In this case, secondary units were chosen using a grouping sample that was stratified by region (COCHRAN, 1977). The parameters used in this calculation were the status of the animal (positive or negative), region to which the sampled herd belonged, identification of the herd in the study and assigned weight of each sampled animal, where the weight is calculated using the following formula (DEAN et al., 1994):

$$
\text { weight }=\frac{\text { females } \geq 24 \text { months in region }}{\text { females } \geq 24 \text { months in sampled farms }} * \frac{\text { females } \geq 24 \text { months in sampled herd }}{\text { females } \geq 24 \text { months sampled in herd }}
$$

The first factor in this formula represents the level to which each selected animal represents the regions, and the second represents the level to which each animal represents the herd.

\section{Study of risk factors}

For the combined data for the state, a crosssectional study was conducted. Two groups of herds (positive or negative) were formed. These groups were compared with regard to the variables evaluated in the epidemiological questionnaire, which enabled the measurement of the strength of the association of each of these variables with the presence of Leptospira spp infection. In each herd, 20 variables linked to the breeding type and management practices were analyzed.

The variable categories were organized by increasing risk (CASTRO et al., 2008; OLIVEIRA et al., 2010). These variables were re-categorized as necessary. The lowest risk category was used as a basis of comparison for the other categories. Quantitative variables were also categorized into quartiles.

The analysis of risk factors was performed in two stages: univariate and multivariate analysis. Univariate analysis was conducted to verify the association between risk variables and the status of a herd using the chi-squared $\left(\chi^{2}\right)$ and Fisher's exact test; Leptospira spp infection status was coded 0 (absence of a seropositive animal) and 1 (presence of at least one seropositive animal). Variables of univariate analysis having a $p$ value $\geq 0.20$ were subjected to additional analysis. A multiple logistic regression analysis was performed (HOSMER; LEMESHOW, 1989) using the SPSS version 9.0 software (SPSS INC, 1999).

\section{Geoprocessing}

For geoprocessing, the geographic coordinates (latitude and longitude) of each farm were entered into a database program in Microsoft ${ }^{\circledR}$ Excel 2000 and analyzed using ArcGIS 9 software, version 9.3 (ESRI), to create the map. The apparent prevalence of bovine leptospirosis in the herds was the selected parameter in the program for creating the initial epidemiological map. The final risk map or Kernel analysis was generated using a ArcGIS Spatial Analyst tool, Feature density, to define the areas of epidemiological risk of disease. The margin of error (d) was calculated using the formula:

$$
\begin{aligned}
& \mathrm{d}=\mathrm{t}[(\mathrm{N}-\mathrm{n}) /(\mathrm{N}-1)] \cdot 1 / 2[(\mathrm{P} \times \mathrm{Q} / \mathrm{n}] \cdot 1 / 2 \\
& \mathrm{t}=\text { constant rate used to calculate the error }(4,96) ; \\
& \mathrm{N}=\text { Total number of municipalities; } \\
& \mathrm{n}=\text { Number of municipalities with positive cases; } \\
& \mathrm{P} \times \mathrm{Q}=\text { Probability of events }(2500)
\end{aligned}
$$

\section{Results}

Prevalence of Leptospira spp in animals and herds

The apparent prevalence of animals with serum antibodies against any one of the 22 serovars of Leptospira spp in the seven regions and in total for the state of Paraná is shown in Table 2. 
Table 2. Apparent prevalence of bovine Leptospira spp-seropositive animals in the regions of Paraná State, Brazil.

\begin{tabular}{|c|c|c|c|c|}
\hline \multirow{2}{*}{ Regions } & \multicolumn{2}{|c|}{ Animals } & \multirow{2}{*}{ Prevalence (\%) } & \multirow{2}{*}{$95 \%$ CI } \\
\hline & Sampled & Positive & & \\
\hline 1 & 2730 & 802 & 41.13 & $34.07-48.20$ \\
\hline 2 & 2512 & 912 & 47.29 & $39.33-55.25$ \\
\hline 3 & 2195 & 590 & 34.89 & $27.70-42.09$ \\
\hline 4 & 1880 & 647 & 48.09 & $41.29-54.89$ \\
\hline 5 & 1898 & 291 & 22.96 & $14.33-31.60$ \\
\hline 6 & 1271 & 221 & 28.59 & $18.70-38.48$ \\
\hline 7 & 1677 & 224 & 24.43 & $15.31-33.56$ \\
\hline Total & 14163 & 3687 & 37.70 & $34.54-40.86$ \\
\hline
\end{tabular}

Table 3 presents the apparent herd prevalence of Leptospira spp in each of the seven regions and in total for the state of Paraná.

Table 3. Apparent prevalence of bovine Leptospira spp seropositive herds in the regions of Paraná State, Brazil.

\begin{tabular}{|c|c|c|c|c|}
\hline \multirow{2}{*}{ Regions } & \multicolumn{2}{|c|}{ Herds } & \multirow{2}{*}{ Prevalence $(\%)$} & \multirow{2}{*}{$95 \%$ CI } \\
\hline & Sampled & Positive & & \\
\hline 1 & 283 & 220 & 77.74 & $72.44-82.45$ \\
\hline 2 & 280 & 231 & 82.50 & $77.53-86.76$ \\
\hline 3 & 274 & 163 & 59.49 & $53.42-65.35$ \\
\hline 4 & 274 & 181 & 66.06 & $60.12-71.65$ \\
\hline 5 & 279 & 97 & 34.77 & $29.19-40.67$ \\
\hline 6 & 279 & 77 & 27.60 & $22.44-33.24$ \\
\hline 7 & 257 & 103 & 40.08 & $34.04-46.35$ \\
\hline Total & 1926 & 1072 & 54.28 & 52.05-56.51 \\
\hline
\end{tabular}

Table 4. Apparent prevalence of Leptospira spp infection stratified by breeding type (beef, dairy and mixed) in regions of Paraná State, Brazil.

\begin{tabular}{ccccccc}
\hline \multirow{2}{*}{ Regions } & \multicolumn{5}{c}{ Leptospira spp herd prevalence } \\
\cline { 2 - 7 } & \multicolumn{2}{c}{ Beef } & \multicolumn{3}{c}{ Dairy } & \multicolumn{1}{c}{ Mixed } \\
\cline { 2 - 7 } & $\mathbf{\%}$ & $\mathbf{9 5 \%}$ CI & $\mathbf{9 5 \%}$ CI & \% & $\mathbf{9 5 \% ~ C I ~}$ \\
\hline 1 & 81.01 & $70.62-88.96$ & 83.67 & $74.84-90.37$ & 69.81 & $60.13-78.35$ \\
2 & 90.91 & $81.25-96.59$ & 81.56 & $74.16-87.59$ & 76.39 & $64.91-85.60$ \\
3 & 81.48 & $68.57-90.74$ & 53.33 & $42.51-63.93$ & 54.61 & $45.65-63.36$ \\
4 & 81.25 & $69.54-89.92$ & 61.39 & $51.18-70.91$ & 61.68 & $51.78-70.91$ \\
5 & 54.17 & $32.82-74.45$ & 32.89 & $25.50-40.97$ & 33.33 & $24.31-43.35$ \\
6 & 42.86 & $26.32-60.65$ & 32.00 & $23.02-42.08$ & 20.57 & $14.23-28.18$ \\
7 & 75.00 & $47.62-92.73$ & 42.57 & $32.79-52.81$ & 33.81 & $26.01-42.32$ \\
Total & $\mathbf{7 6 . 9 2}$ & $\mathbf{7 2 . 0 6 - 8 1 . 3 1}$ & $\mathbf{5 5 . 1 7}$ & $\mathbf{5 1 . 6 1 - 5 8 . 6 9}$ & $\mathbf{4 1 . 1 8}$ & $\mathbf{4 3 . 6 6 - 5 0 . 7 1}$ \\
\hline
\end{tabular}


Prevalence of Leptospira spp serovars

The prevalent serovars of Leptospira spp in herds and seropositive animals in the state of Paraná are shown in Tables 5 and 6.

Table 5. Serovars of Leptospira spp in seropositive animals of Paraná State, Brazil.

\begin{tabular}{lcc}
\hline \multicolumn{1}{c}{ Serovar } & Proportion of positive animals & Prevalence (\%) \\
\hline Hardjo & $2036 / 3687$ & 55.22 \\
Tarassovi & $421 / 3687$ & 11.42 \\
Hardjo and Wolffi & $321 / 3687$ & 8.71 \\
Coagglutination & $305 / 3687$ & 8.27 \\
Grippotyphosa & $144 / 3687$ & 3.91 \\
Bratislava & $85 / 3687$ & 2.30 \\
Wolffi & $82 / 3687$ & 2.22 \\
Autumnalis & $79 / 3687$ & 2.14 \\
Australis & $55 / 3687$ & 1.49 \\
Pomona & $33 / 3687$ & 0.89 \\
Pyrogenes & $27 / 3687$ & 0.73 \\
Copenhageni & $21 / 3687$ & 0.57 \\
Shermani & $18 / 3687$ & 0.49 \\
Canicola & $13 / 3687$ & 0.36 \\
Castellonis & $13 / 3687$ & 0.36 \\
Sentot & $11 / 3687$ & 0.30 \\
Icterohaemorrhagiae & $9 / 3687$ & 0.24 \\
Butembo & $9 / 3687$ & 0.24 \\
Bataviae & $2 / 3687$ & 0.05 \\
Cynopteri & $1 / 3687$ & 0.03 \\
Panama & $1 / 3687$ & 0.03 \\
Whitcombi & $1 / 3687$ & 0.03 \\
\hline
\end{tabular}

Table 6. Serovars of Leptospira spp in seropositive herds of Paraná State, Brazil.

\begin{tabular}{lccc}
\hline \multicolumn{1}{c}{ Serovar } & Proportion of positive herds & Prevalence (\%) & Continue ... \\
\hline Hardjo & $705 / 1072$ & 65.76 & $62.84-68.60$ \\
Hardjo and Wolffi & $81 / 1072$ & 7.57 & $6.04-9.30$ \\
Tarassovi & $80 / 1072$ & 7.47 & $5.97-9.20$ \\
Grippotyphosa & $64 / 1072$ & 5.97 & $4.63-7.56$ \\
Bratislava & $24 / 1072$ & 2.24 & $1.44-3.31$ \\
Wolffi & $22 / 1072$ & 2.05 & $1.29-3.09$ \\
Autumnalis & $17 / 1072$ & 1.58 & $0.93-2.53$ \\
Shermani & $17 / 1072$ & 1.58 & $0.93-2.53$ \\
Australis & $11 / 1072$ & 1.03 & $0.51-1.83$ \\
Canicola & $11 / 1072$ & 1.03 & $0.51-1.83$ \\
Pomona & $10 / 1072$ & 0.93 & $0.45-1.71$ \\
Pyrogenes & $10 / 1072$ & 0.93 & $0.45-1.71$ \\
\hline
\end{tabular}




\begin{tabular}{lllc}
\hline Sentot & $05 / 1072$ & 0.47 & $\ldots .15-1.08$ \\
Castellonis & $04 / 1072$ & 0.37 & $0.10-0.95$ \\
Icterohaemorrhagiae & $04 / 1072$ & 0.37 & $0.10-0.95$ \\
Copenhageni & $03 / 1072$ & 0.28 & $0.06-0.81$ \\
Butembo & $02 / 1072$ & 0.19 & $0.02-0.67$ \\
Cynopteri & $01 / 1072$ & 0.09 & $* *$ \\
Hebdomadis & $01 / 1072$ & 0.09 & $* *$ \\
\hline
\end{tabular}

Analysis of risk factors

Tables 7 and 8 present the results of the univariate analysis of potential risk factors associated with infection for each of the 22 serovars of Leptospira spp and serovar Hardjo, respectively, in herds of Paraná state.

Table 7. Distribution of the variables analyzed as possible risk factors for Leptospira spp in cattle herds from Paraná State, Brazil.

\begin{tabular}{lccc}
\hline \multicolumn{1}{c}{ Variables } & Exposed/Positives & Exposed/Negatives & p \\
\hline Semi-confined/confined herd & $197 / 1068$ & $197 / 844$ & 0.009 \\
Beef cattle breeding & $260 / 1068$ & $78 / 850$ & 0.000 \\
Pure breeds & $411 / 1039$ & $229 / 825$ & 0.000 \\
Presence of $>49$ bovines & $424 / 1072$ & $67 / 854$ & 0.000 \\
Presence of $>$ 20 females $\geq 24$ months & $407 / 1066$ & $63 / 847$ & 0.000 \\
Use of artificial insemination & $168 / 1044$ & $200 / 834$ & 0.000 \\
Presence of sheep and goats & $182 / 1072$ & $79 / 854$ & 0.000 \\
Presence of horses & $810 / 1072$ & $445 / 854$ & 0.000 \\
Presence of pigs & $707 / 1072$ & $602 / 854$ & 0.034 \\
Presence of dogs & $964 / 1072$ & $779 / 854$ & 0.337 \\
Presence of wild animals & $346 / 1072$ & $194 / 854$ & 0.000 \\
History of abortion & $225 / 1053$ & $130 / 833$ & 0.001 \\
Leave products of abortion in the field & $346 / 787$ & $270 / 534$ & 0.000 \\
Buying animals for reproduction & $615 / 1066$ & $286 / 846$ & 0.000 \\
Selling animals for reproduction & $308 / 1060$ & $121 / 841$ & 0.000 \\
Slaughter animals on the farm & $109 / 1053$ & $290 / 830$ & 0.000 \\
Rental of grazing areas & $189 / 1068$ & $63 / 845$ & 0.000 \\
Common grazing areas & $164 / 1065$ & $84 / 848$ & 0.000 \\
Presence of flooded areas & $256 / 1064$ & $226 / 836$ & 0.139 \\
Presence of calving pens & $345 / 1064$ & $165 / 826$ & 0.000 \\
\hline
\end{tabular}


Table 8. Distribution of the variables analyzed as possible risk factors for serovar Hardjo in cattle herds from Paraná State, Brazil.

\begin{tabular}{lccc}
\hline \multicolumn{1}{c}{ Variables } & Exposed/Positives & Exposed/Negatives & p \\
\hline Semi-confined/confined herd & $122 / 627$ & $197 / 845$ & 0.076 \\
Beef cattle breeding & $167 / 627$ & $79 / 851$ & 0.000 \\
Pure breeds & $249 / 609$ & $229 / 826$ & 0.000 \\
Presence of $>$ 49 bovines & $274 / 629$ & $68 / 855$ & 0.000 \\
Presence of $>$ 20 females $\geq 24$ months & $261 / 626$ & $63 / 848$ & 0.000 \\
Use of artificial insemination & $89 / 613$ & $200 / 835$ & 0.000 \\
Presence of sheep and goats & $116 / 629$ & $79 / 855$ & 0.000 \\
Presence of horses & $492 / 629$ & $444 / 855$ & 0.000 \\
Presence of pigs & $415 / 629$ & $603 / 855$ & 0.062 \\
Presence of dogs & $559 / 629$ & $780 / 855$ & 0.131 \\
Presence of wild animals & $203 / 629$ & $194 / 855$ & 0.000 \\
History of abortion & $134 / 613$ & $130 / 834$ & 0.002 \\
Leave products of abortion in the field & $216 / 466$ & $271 / 535$ & 0.012 \\
Buying animals for reproduction & $375 / 627$ & $286 / 847$ & 0.000 \\
Selling animals for reproduction & $195 / 624$ & $121 / 842$ & 0.000 \\
Slaughter animals on the farm & $56 / 619$ & $290 / 831$ & 0.000 \\
Rental of grazing áreas & $130 / 626$ & $63 / 846$ & 0.000 \\
Common grazing áreas & $100 / 624$ & $84 / 849$ & 0.000 \\
Presence of flooded areas & $148 / 624$ & $225 / 837$ & 0.170 \\
Presence of calving pens & $203 / 623$ & $165 / 827$ & 0.000 \\
\hline
\end{tabular}

The risk factors associated with infection for any serovar of Leptospira spp and serovar Hardjo, identified in the multivariate logistic regression analysis, are described in Tables 9 and 10 , respectively.

Table 9. Results of the multiple logistic regression analysis for risk factors associated with Leptospira spp infection in cattle herds with reproductive activity in the state of Paraná, Brazil.

\begin{tabular}{lccccc}
\hline \multicolumn{1}{c}{ Variables } & Cases & Exposed & p value & OR $^{\mathbf{1}}$ & $\mathbf{9 5 \% ~ C I ~}$ \\
\hline Rental grazing areas & 189 & 252 & 0.000 & 1.91 & $1.36-2.68$ \\
Presence of horses & 810 & 1255 & 0.000 & 1.59 & $1.28-1.97$ \\
Presence of $>$ 20 females $\geq 24$ months & 407 & 470 & 0.000 & 2.25 & $1.46-3.49$ \\
Presence of $>$ 49 bovines & 424 & 491 & 0.000 & 2.78 & $1.82-4.26$ \\
Buying animals for reproduction & 615 & 901 & 0.000 & 1.96 & $1.59-2.41$ \\
Presence of calving pens & 345 & 510 & 0.022 & 1.32 & $1.04-1.68$ \\
\hline
\end{tabular}

$\mathrm{R}^{2}=24,80 \%$

${ }^{1}$ Odds ratio 
Table 10. Results of the multiple logistic regression analysis for risk factors associated with serovar Hardjo infection in cattle herds with reproductive activity in the state of Paraná, Brazil.

\begin{tabular}{lccccc}
\hline \multicolumn{1}{c}{ Variables } & Cases & Exposed & p value & OR $^{\mathbf{1}}$ & $\mathbf{9 5 \% ~ C I ~}$ \\
\hline Presence of $>49$ bovines & 274 & 342 & 0.000 & 3.05 & $1.94-4.80$ \\
Presence of $>$ 20 females $\geq 24$ months & 261 & 324 & 0.000 & 2.38 & $1.50-3.79$ \\
Presence of horses & 492 & 936 & 0.000 & 1.87 & $1.45-2.43$ \\
Buying animals for reproduction & 375 & 661 & 0.000 & 2.14 & $1.68-2.72$ \\
Rental grazing areas & 130 & 193 & 0.000 & 2.22 & $1.54-3.21$ \\
\hline
\end{tabular}

$\mathrm{R}^{2}=30,10 \%$

${ }^{1}$ Odds ratio

\section{Geoprocessing}

The spatial visualization of herds seropositive to Leptospira spp identified the North/Northwest and Southwest regions as the areas of higher risk of disease occurrence in the state, as shown in Figure 2.

Figure 2. Spatial distribution of the risk areas for bovine leptospirosis in farms located in the State of Paraná, Brazil.

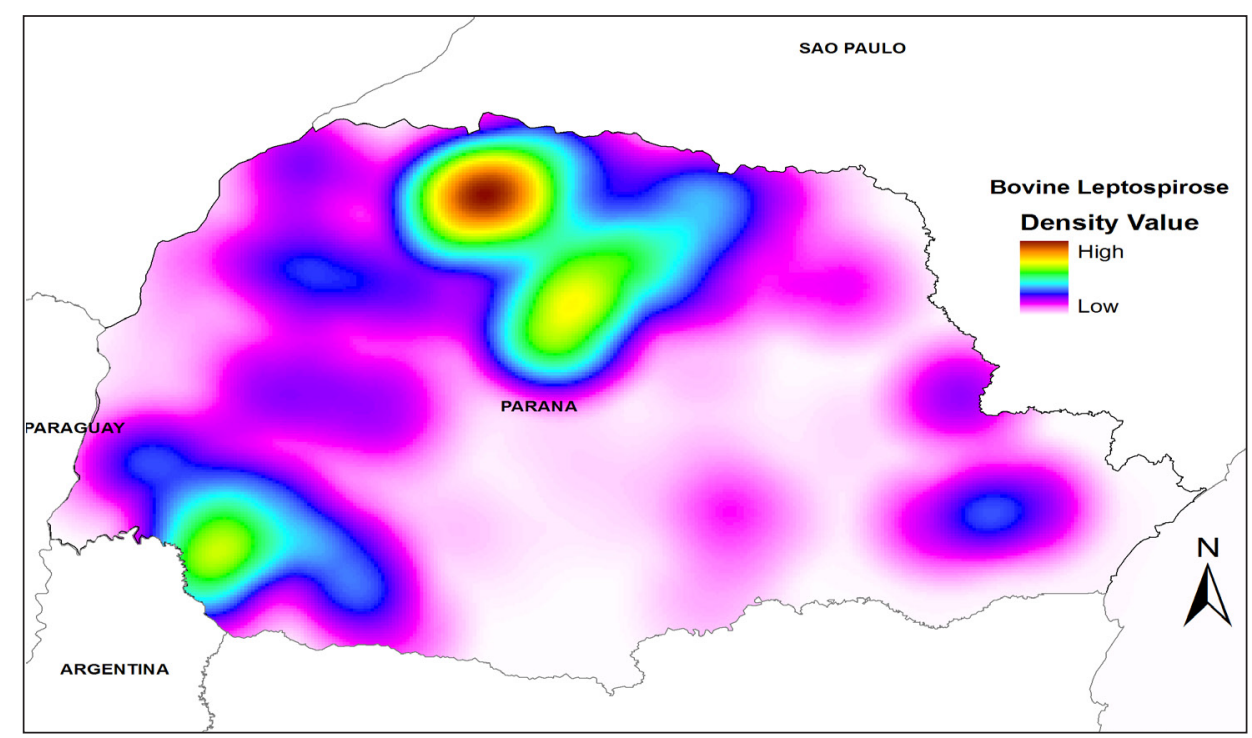

\section{Discussion}

The seroprevalence of Leptospira spp shows that the disease is widely distributed in all regions of the state of Paraná. In this study, the herds selected for sampling had no history of vaccination against leptospirosis; thus, the prevalence of farms that are a focus represents natural contact with the microorganism, showing the epidemiological situation in the state during the study period.
The Northwest, Midwestern/North and MidSouth regions represented by bovine production regions 1, 2 and 4 had the highest apparent prevalence levels (Table 2 and 3). At the time of this study, these regions contained $60 \%$ of all cattle in the state and presented the highest median number of cattle in each herd. Several studies have shown an association between herd size and the presence of leptospirosis (CASTRO et al., 2008; OLIVEIRA et al., 2010). 
According to Oliveira et al. (2010), larger herds with high animal density present greater probabilities of infection by Leptospira spp. However, the prevalence of leptospirosis in a herd will primarily depend on the presence of carrier animals that eliminate the microorganism through urine, the resulting contamination of the environment with live leptospires, their survival in the environment and the contact of susceptible animals with the agent (NIANG et al., 1994).

The apparent herd prevalence of Leptospira spp infection in the entire state, stratified by type of breeding, was greater in beef cattle herds $(76.92 \%)$ than in dairy (55.17\%) and mixed herds (41.18\%). Vasconcellos et al. (1997) examined the dairy and beef cattle herds in six Brazilian states and found a higher frequency of seropositivity for Leptospira spp among beef cattle. The relevant characteristics of beef cattle management may include a lower rate of cow replacement as well as a lower level of sanitary control of reproductive diseases compared to dairy farms. According to Prescott et al. (1988), different management practices used in beef cattle herds can influence the maintenance of Leptospira spp in this type of breeding.

The spatial visualization of positive herds to Leptospira spp by MAT (Figure 2) allowed identification of the areas at higher risk of disease occurrence in the state. Through the use of the Kernel Density estimator, it was verified that the spatial distribution of bovine leptospirosis in the state of Paraná is not uniform; a higher concentration of the disease is visible in certain areas, mainly between North/Northwest and Southwest regions. The North/Northwest region represents the largest population of beef cattle and presents the highest apparent prevalence levels in the state. Because the areas of Paraná form a border with the states of São Paulo and Mato Grosso do Sul, there is a high frequency of movement of animals between these three states, mainly of beef cattle, which could increase the risk of infection by Leptospira spp. The Southwest region is one of the largest milk producing regions in the state and is characterized by family farming, in which the sale of milk is the primary source of monthly income. The dairy farms in this region are characterized by a high animal turnover rate, due to the disposal of animals with unsatisfactory milk production. Thus, the high rate of animal replacement could facilitate the introduction of diseases, such as leptospirosis, when performed without taking the proper biosecurity measures.

Serovar Hardjo (55.22\%) was the most frequently identified agent among the animals studied, followed by Tarassovi (11.42\%), the association of Hardjo and Wolffi (8.71\%), Grippotyphosa (3.91\%) and Bratislava (2.30\%) (Table 5). Similarly, Hardjo $(65.76 \%)$, the association of serovars Hardjo and Wolffi (7.57\%), Tarassovi (7.47\%), Grippotyphosa (5.97\%) and Bratislava (2.24\%) were the most frequent serovars among the cattle herds analyzed (Table 6).

The predominance of serovar Hardjo detected in this study agrees with studies conducted in other states (OLIVEIRA et al., 2001; ARAUJO et al., 2005; CASTRO et al., 2008; FIGUEIREDO et al., 2009; OLIVEIRA et al., 2010). The serovar Hardjo is adapted to the bovine species, which can behave as a reservoir and maintains the disease in the herd (MOREIRA, 1994). The higher frequency of seropositive animals to serovar Hardjo detected in this study suggests that the most important source of infection for these animals is other infected cattle.

The detection of serovars considered incidental to the bovine species suggests the participation of domestic and wild species in the transmission of Leptospira spp for the animals studied. Serovars Tarassovi and Grippotyphosa were detected most frequently and are associated with wild animals (HIDALGO; SULZER, 1984; PELLEGRIN et al., 1999), raising the suspicion of involvement of these wild species as reservoirs and potential transmitters of these serovars to the animals studied. The presence of seropositive animals to serovar Bratislava, which normally circulates in the swine population (ELLIS; 
THIERMANN, 1986), suggests a close proximity between the cattle and swine present in the region. According to Ellis (1984), infection with Leptospira spp in domestic animals is determined by factors such as contact between animal species, serovars in the region and environmental and climatic conditions, as well as herd management and direct or indirect opportunities for infection.

A high frequency of cross-reactions between serovars Hardjo and Wolffi was observed; however, the isolated occurrence of serovar Wolffi was lower than that of Hardjo. The cross-reactivity between these serovars may occur because they belong to the same serogroup, Sejroe, and share similar antigenic determinants (COSTA et al., 1998). To determine the frequency of cross-reactions between serovars Hardjo and Wolffi and the importance of their inclusion in the antigenic battery, cross-reactions between these two serovars were not excluded in the analysis.

The analysis of risk factors was initially performed by considering the positive herds for any serovar and then considering only the most common serovar (Hardjo) in the herds studied. These analyses were performed to determine which risk factors are associated with any serovar and with serovar Hardjo. However, the risk factors found in these two analyses were similar, due to the high prevalence of serovar Hardjo in the herds.

The farms that rent grazing areas had a greater chance of being positive than those that did not rent. The risk of disease introduction through the practice of renting grazing areas is high, especially if the introduced animals in a herd are eliminating the agent in urine.

The purchase of infected animals is widely reported as a major factor for the introduction of leptospirosis in herds (CASTRO et al., 2008; OLIVEIRA et al., 2010; HASHIMOTO et al., 2012). In this study, farms that introduce new animals had a greater chance of being positive than farms with a closed population. These data show the importance of this variable as a factor for introduction of disease to farms when the purchase is made without animal health control.

Variables related to the size of the herd are associated with disease risk. According to Oliveira et al. (2010), increasing herd size can result in an increased probability ofleptospirosis, making it more persistent and hindering the control and eradication of the disease. Thus, higher numbers of animals in the herd means a greater risk of introduction and spread of the disease. This agrees with the results of this study, as the highest prevalence of infection is at the farms with the largest herds.

The presence of horses, identified as a risk factor for the disease, demonstrates the possibility of contact between these animals and the animals studied. In the state of Paraná, the use of horses as service animals in beef herds is very common; this close contact can facilitate the transmission of leptospirosis between these animal species. According to Murhekar et al. (1998), the cycle of leptospirosis transmission involves the interaction between one or more species of hosts and reservoirs, as well as favorable environmental factors for the microorganism.

The properties that use calving pens had a greater chance of being positive than farms that did not use calving pens. The use of calving pens is a good management practice that facilitates birth assistance and calf management. However, when this practice is performed in an uncontrolled or unhygienic manner, it can facilitate the transmission of diseases. The high concentration of animals in calving pens results in the accumulation of urine and increased contact with the contaminated products of birth, abortion and reproductive failures associated with animal handling; these potential exposures may predispose animals to Leptospira spp infection.

\section{Conclusions}

Epidemiological studies on bovine leptospirosis 
in the state of Paraná are important because they contribute to animal heath monitoring in the state, thus enabling control of the disease and minimizing losses. This is considered essential for the state of Paraná, where livestock production is an important economic activity.

The analysis of the apparent prevalence of animals and herds with Leptospira spp infection during this study period shows that the bacteria is widely distributed across all regions of the state, and highlights the areas with a higher risk of disease occurrence in the state. Using the Kernel Density estimator allowed stratification of the state into risk areas according to the spatial distribution of leptospirosis, which enables the planning of appropriate control actions targeted at these areas. The results of the risk factors analysis indicate that characteristics of each farm and its management practices are associated with Leptospira spp infection and should be considered in disease prevention programs. The epidemiological results obtained in this study may assist in the development of control strategies, particularly in the areas at higher risk for leptospirosis.

\section{Acknowledgements}

The authors would like to thank to the Secretary of Agriculture of Paraná State and the Ministry of Agriculture, Livestock and Food Supply. This study was financially supported by Aperfeiçoamento de Pessoal de Nível Superior (CAPES).

\section{References}

ARAUJO, V. E. M.; MOREIRA, E. C.; NAVEDA, L. A. B.; SILVA, J. A.; CONTRERAS, R. L. Frequência de aglutininas anti-Leptospira interrogans em soros sanguíneos de bovinos em Minas Gerais de 1980 a 2002. Arquivo Brasileiro de Medicina Veterinária e Zootecnia, Belo Horizonte, v. 57, n. 2, p. 430-435, 2005.

BRASIL. Ministério da Saúde. Manual de leptospirose. 2. ed. Brasília: [s.n.], 1995. 98 p.
CASTRO, V.; AZEVEDO, S. S.; GOTTI, T. B.; BATISTA, C. S. A.; GENTILI, J.; MORAES, Z. M.; SOUZA, G. O.; VASCONCELLOS, S. A.; GENOVEZ, M. E. Soroprevalência da leptospirose em fêmeas bovinas em idade reprodutiva no estado de São Paulo, Brasil. Arquivos do Instituto Biológico, São Paulo, v. 75, n. 1, p. 3-11, 2008.

COCHRAN, W. G. Sampling techniques. New York: John Wiley \& Sons, 1977. 484 p.

COSTA, M. C. R.; MOREIRA, E. C.; LEITE, R. C.; MARTINS, N. R. S. Avaliação da imunidade cruzada entre Leptospira hardjo e L. wolffi. Arquivo Brasileiro de Medicina Veterinária e Zootecnia, Belo Horizonte, v. 50, n. 1, p. 11-17, 1998.

DEAN, A. G.; DEAN, J. A.; COLOMBIER, D.; BRENDEL, K. A.; SMITH, D. C.; BURTON, A. H.; DICKER, R. C.; SULLIVAN, K.; FAGAN, R. F.; ARNER, T. G. Epi-Info, version 6. A word processing database and statistics program for epidemiology on microcomputers. Atlanta: CDC, 1994. 599 p.

ELLIS, W. A. Bovine leptospirosis in the tropics: prevalence, pathogenesis and control. Preventive Veterinary Medicine, Colorado, v. 2, n.1-4, p. 411-421, 1984.

ELLIS, W. A.; THIERMANN, A. B. Isolation of leptospiras from genital tracts of Iowa cows. American Journal of Veterinary Research, Chicago, v. 47, n. 8, p. 1694-1696, 1986.

FAINE, S.; ADLER, B.; BOLIN, C.; PEROLAT, P. Leptospira and leptospirosis. $2^{\text {th }}$ ed. Melbourne: Medical Science, 1999. $272 \mathrm{p}$.

FAVERO, A. C. M.; PINHEIRO, S. R.; VASCONCELLOS, S. A.; MORAIS, Z. M.; FEREIRA, F.; FERREIRA NETO, J. S. Sorovares de leptospiras predominantes em exames sorológicos de bubalinos, ovinos, caprinos, equinos, suínos e cães de diversos estados brasileiros. Ciência Rural, Santa Maria, v. 32, n. 4, p. 613-619, 2002.

FIGUEIREDO, A. O.; PELLEGRIN, A. O.; GONÇALVES, V. S. P.; FREITAS, E. B.; MONTEIRO, L. A. R. C.; OLIVEIRA, J. M.; OSÓRIO, A. L. A. R. Prevalência e fatores de risco para a leptospirose em bovinos de Mato Grosso do Sul. Pesquisa Veterinária Brasileira, Seropédica, v. 29, n. 5, p. 375-381, 2009.

GENOVEZ, M. E.; OLIVEIRA, J. C.; CASTRO, V.; FERRARI, C. I. L.; SCARCELLI, E.; CARDOSO, M. V.; PAULIN, L. M.; LANÇA NETO, P. Serological profile of a nelore herd presenting endemic leptospirosis and submited to vaccination. Arquivos do Instituto Biológico, São Paulo, v. 1, n. 4, p. 411-416, 2004. 
HASHIMOTO, V. Y.; DIAS, J. A.; SPOHR, K. A. H.; SILVA, M. C. P.; ANDRADE, M. G. H.; MULLER, E. E.; FREITAS, J. C. Prevalência e fatores de risco associados à Leptospira spp em rebanhos bovinos da região centrosul do estado do Paraná. Pesquisa Veterinária Brasileira, Seropédica, v. 32, n. 2, p. 99-105, 2012.

HASHIMOTO, V. Y.; GARCIA, J. L.; SPOHR, K. A. H.; SILVA, F. G.; ALVES, L. S.; FREITAS, J. C. Prevalência de anticorpos contra Leptospira spp. em bovinos, caninos, eqüinos, ovinos e suínos do município de Jaguapitã, estado do Paraná, Brasil. Arquivos do Instituto Biológico, São Paulo, v. 77, n. 3, p. 521-524, 2010.

HIDALGO, J. L.; SULZER, K. R. Six new leptospiral serovars isolated from wild animals in Peru. Journal of Clinical Microbiology, Barcelona, v. 19, n. 6, p. 944-945, 1984.

HOSMER JUNIOR, D. W.; LEMESHOW, S. Applied logistic regression. New York: Wiley, 1989. 307 p.

MOREIRA, E. C. Avaliação de métodos para erradicação de leptospiroses em bovinos leiteiros. 1994. Tese (Doutorado em Ciência Animal) - Universidade Federal de Minas Gerais, UFMG, Belo Horizonte.

MURHEKAR, M.V.; SUGUNAN,A.P.; VIJAYACHARI, P.; SHARMA, S.; SEHGAL, S. C. Risk factors in the transmission of leptospiral infection. The Indian of Medical Research, New Delhi, Índia, v. 107, p. 208-223, 1988.

NIANG, M.; WILL, L. A.; KANE, M.; DIALLO, A. A.; HUSSAIN, M. Seroprevalence of leptospiral antibodies among dairy cattle kept in communal corrals in periurban areas of Bamako, Mali, West Africa. Preventive Veterinary Medicine, Colorado, v. 18, n. 4, p. 259-265, 1994.

NOORDHUIZEN, J. P. T. M.; FRANKENA, K.; VAN DER HOOFD, C. M.; GRAAT, E. A. M. Application of Quantitative Methods in Veterinary Epidemiology. Wageningen: Wageningen Press, 1997. 445 p.

OLIVEIRA, A. A.; MOTA, R. A.; PEREIRA, G. C.; LANGONI, H.; SOUZA, M. I.; NAVEGANTES, W. A.; SÁ, M. E. Soroprevalence of bovine leptospirosis in Garanhuns municipal district, Pernambuco state, Brazil. The Onderstepoort Journal of Veterinary Research, Durbanville, África do Sul, v. 68, n. 4, p. 275-279, 1997, 2001.
OLIVEIRA, F. C. S.; AZEVEDO, S. S.; PINHEIRO, S. R.; BATISTA, C. S. A.; MORAES, Z. M.; SOUZA, G. O.; GONÇALVES, A. P.; VASCONCELLOS, S. A. Fatores de risco para a leptospirose em fêmeas bovinas em idade reprodutiva no estado da Bahia, Nordeste do Brasil. Pesquisa Veterinária Brasileira, Seropédica, v. 30, n. 5, p. 398-402, 2010.

PARANÁ. Secretaria de Estado da Agricultura e Abastecimento. Departamento de Fiscalização. Programa Estadual de Controle e Erradicação da Brucelose e Tuberculose Animal. Manual de procedimentos: estudo soroepidemiológico da brucelose bovina e bubalina. Curitiba: [s.n.], 2001.21 p.

PELLEGRIN, A. O.; GUIMARÃES, P. H. S.; SERENO, J. R. B.; FIGUEIREDO, J. P.; LAGE, A. P.; MOREIRA, E. C.; LEITE, R. C. Prevalência da leptospirose em bovinos do Pantanal Mato-Grossense. Corumbá: Embrapa Pantanal, 1999. p. 1-9. (Comunicado técnico, 22).

PRESCOTT, J. F.; MILLER, R. B.; NICHOLSON, V. M.; MARTIN, S. W.; LESNICK, T. Seroprevalence and Association with abortion of leptospirosis in cattle in Ontário. Canadian Journal of Veterinary Research, Ottawa, v. 52, n. 2, p. 210-215, 1988.

STATISTICAL PACKAGE FOR THE SOCIAL SCIENCES - SPSS INC. SPSS base 9.0 user's guide. Chicago, 1999. 740p.

THRUSFIELD, M. Veterinary epidemiology. $2^{\text {th }}$ ed. Cambridge: Blackwell Science, 1995. 610 p.

VASCONCELLOS, S. A.; BARBARINI JUNIOR, B. O.; UMEHARA, O.; MORAIS, Z. M.; CORTEZ, A.; PINHEIRO, S. R.; FERREIRA, F.; FAVERO, A. C. M, FERREIRA NETO, J. S. Leptospirose bovina. Níveis de ocorrência e sorotipos predominantes em rebanhos dos Estados de Minas Gerais, São Paulo, Rio de Janeiro, Paraná, Rio Grande do Sul e Mato Grosso do Sul, período de janeiro a abril de 1996. Arquivos do Instituto Biológico, São Paulo, v. 64, n. 2, p. 7-15, 1997. 
